\title{
Urbanization and its Impact on Agricultural Lands in Growing Cities in Developing Countries: A Case Study of Makurdi, Benue State Nigeria
}

\author{
Yusuf Mohammed Bakoji ${ }^{*}$, Elijah Elizabeth, Anita Humshe Philip, Mohammed Salim Isa, \\ Umar Jauro Abba
}

Department of Geography, Faculty of Social \& Management Sciences, Taraba State University, Jalingo, Nigeria

Email address:

mbyusuf36@yahoo.com (Y. M. Bakoji), sirlymeesah@gmail.com (E. Elizabeth), humshe58@gmail.com (A. H. Philip), uajumar@gmail.com (M. S. Isa), irayusuf29@yahoo.com (U. J. Abba)

${ }^{*}$ Corresponding author

\section{To cite this article:}

Yusuf Mohammed Bakoji, Elijah Elizabeth, Anita Humshe Philip, Mohammed Salim Isa, Umar Jauro Abba. Urbanization and its Impact on Agricultural Lands in Growing Cities in Developing Countries: A Case Study of Makurdi, Benue State Nigeria. International Journal of Economy, Energy and Environment. Vol. 5, No. 4, 2020, pp. 41-46. doi: 10.11648/j.ijeee.20200504.11

Received: June 18, 2020; Accepted: July 4, 2020; Published: July 17, 2020

\begin{abstract}
Land is a basic, definite and important natural resources which supplies most of man's food. However, urbanization has remains the major threats challenging the sustainability of agricultural lands in most major growing cities of the developing countries. This research work was carried out to assess the impacts of urbanization on arable land in Makurdi town. The study used Remote Sensing and GIS with satellite images to analysis, mapped and quantified the land use types and extent at which agricultural lands are lost to urbanization within the study period. The findings revealed that the land use types had changed significantly within the study period. The result also shown that, the study area has lost $200 \mathrm{~km}^{2}$ of agricultural land representing $19 \%$ of the total landmass to urbanization within the study period. Built -up has gained $336 \mathrm{~km}^{2}$ representing $32 \%$ of the total landmass of the study area within the same period. Thus, the study area has emerged from being predominantly rural area to a city with an appreciable urbanization level. The study recommended that: i. effective and proper management strategies to control urban expansion to agriculture lands by the government are taken such as integrating agricultural land use into urban land use planning. ii. Proactive measure is taken by all stakeholders in the study area towards a better understanding of the changing pattern of land use of the area.
\end{abstract}

Keywords: Urbanization, Agricultural Lands, Growing Cities, Makurdi, Nigeria

\section{Introduction}

Urbanization is particularly rapid and the foremost threat facing arable lands in most major growing cities of the developing world, where globalization, major economic restructuring and lack of rural employment opportunities provoked an exodus from rural areas to urban centers [1-3]. Typically, urbanization is being perpetuated due to the low cost of the agricultural land that is being converted or transformed, accompanied with an increase in accessible transportation network which increases the ability of the rural workforce to move out from the rural areas [4, 5].

According to [6], urbanization is the horizontal or vertical outward extension of urban area over the adjacent agricultural land; it is a natural process which consumes many hectares of arable lands from their surrounding every year. It comes about through the transformation of non-urban land into urban land and such a transformation of land is one way, and once transformed, it is very difficult to return urban land back to the original land use [7, 8]. It also involves both the internal reorganization and outward expansion of the physical structure of urban areas which results in loss of agricultural farmlands and natural beauties [2,9]. Thus, urbanization is determined by how different individual or households, enterprises, businesses, companies (both in private and public sectors) deem fit to locate and build (either legally or illegally), resulting in urban areas expanding haphazardly over the nation's productive arable land. 
Nigeria is one of the most urbanized countries in Africa with estimated urban population of $107,112,526$ persons in 2020 and urbanization rate of $3.5 \%$ annually [10]. According to [4]), the share of urban population out of the total population of Nigeria was less than $48 \%$ in 2010 but has continued to escalate over the years particularly in growing cities such as Makurdi town and its environs [7, 11].

Makurdi, the state capital of Benue State has been experiencing tremendous urban expansion since its inception as a state capital in 1976 [12]. Developmental activities have resulted in the increased population, landscape consumption, modification and alterations which have affected arable lands. Land use types contend strongly with agriculture for space, and because they generate higher rents, they always edge out agriculture except where there are strong and practical land policies that favour agriculture over such land use types [13, 14]. This therefore, called for a concerted effort in assessing the effect of urbanization on arable lands.

However, previous studies had focused so much attention on the growth, infrastructural and environmental problems of megacities and have made no attempts on the impact of urbanization on agricultural lands. Although some authors have made attempts to examine the impact of urbanization on agricultural lands but, most of such studies are concentrated ether in the eastern or southern part of the country with different geographical settings. Therefore, there is dearth of information on the rate of arable land loss due to urbanization in the study area particularly using Remote Sensing (RS) and Geographic Information System (GIS) techniques. While, studies of such will be of interest to ecologists, planners, civil engineers, sociologists, administrators and policy makers as to how much are the expansion effects on arable land and possible solution. Moreover, the integration of Remote Sensing (RS) and Geographic Information Systems (GIS) is a powerful and effective tool in detecting, analyzing, monitoring and mapping urban expansion, urban land use, and land use/land cover changes $[6,10]$. It is for this reason that this research effort is made towards examining the amount of arable land loss to urbanization in the study area using Remote Sensing (RS) and Geographic Information System (GIS) techniques.

\section{Materials and Experiments}

\subsection{The Study Area}

Makurdi town is located between latitude $7^{\circ} 38^{\prime} \mathrm{N}-7^{\circ} 50^{\prime} \mathrm{N}$, and longitude $8^{\circ} 34^{\prime} \mathrm{E}$ and $8^{\circ} 38^{\prime} \mathrm{E}$ (Figure 1). It is situated in the Benue valley in the North Central region of Nigeria. It is traversed by the second largest river in the country, the River Benue. It is about 1,052 square $\mathrm{km}$ [15].

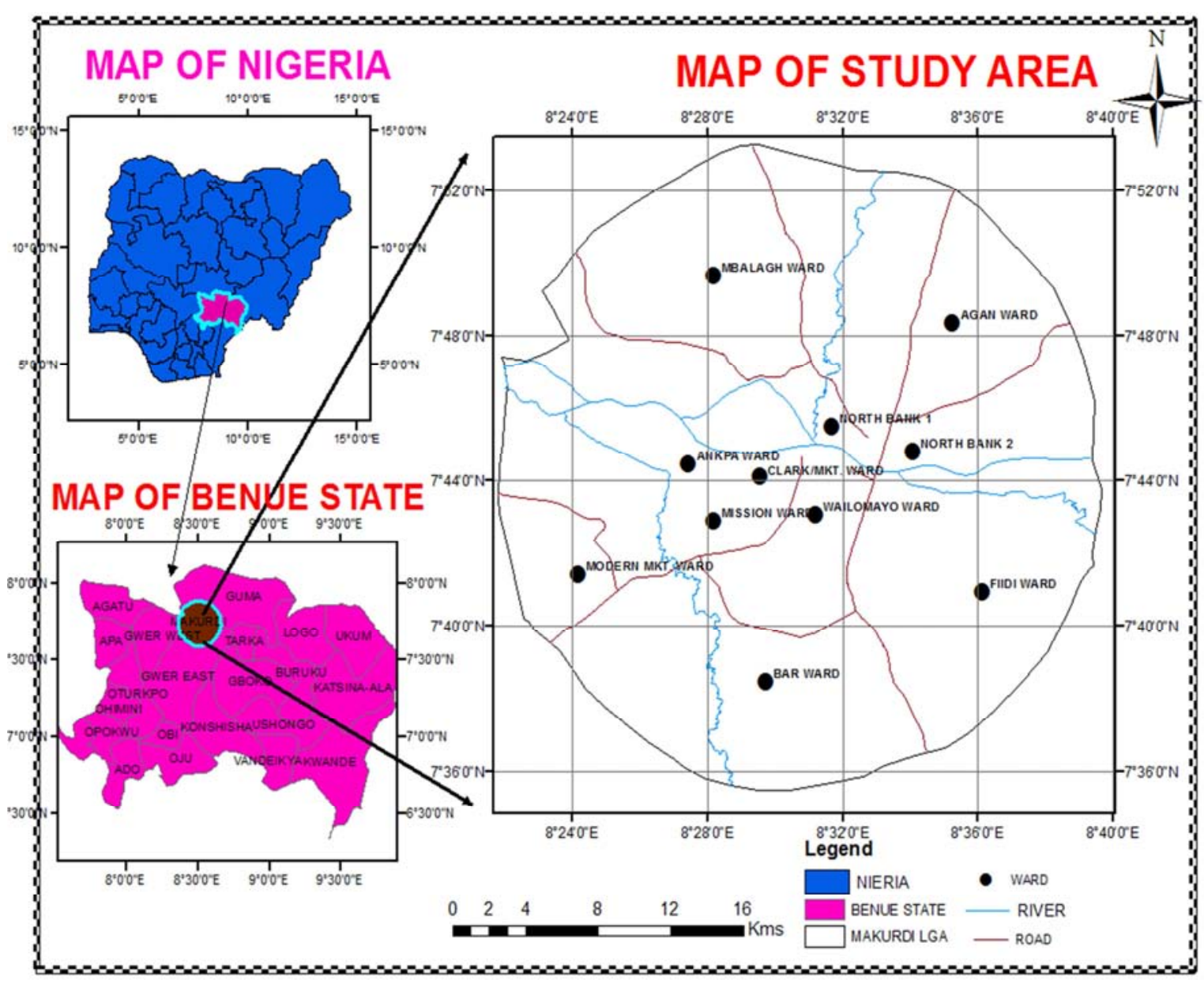

Figure 1. Location map of study area. 
The climate of Makurdi town is that of the tropical wet and dry type, Koppen's Aw classification, with double maxima [16]. The rainy season lasts from April to October, with 5 months of dry season (November to March). Average annual rainfall is approximately $1,173 \mathrm{~mm}$ [15]. Temperature is generally high throughout the year, with February and March as the hottest months. The daily maximum and minimum temperature is about $40^{\circ} \mathrm{C}$ and $22.5^{\circ} \mathrm{C}$ respectively [12].

Makurdi town is located in the plains of the River Benue in the Benue Trough. Its relief is generally low-lying ranging from below $90 \mathrm{~m}$ to $150 \mathrm{~m}$ on the average. There are interfluves in certain parts of the town where elevation is above the average [15] The vegetation of the study area is that of the guinea savannah type and has been adversely affected by human activities leading to the clear-cutting of tree cover in many parts of the town. It is endowed with vast arable land suitable for agricultural purposes [15]. The farm produce found in commercial quantity includes: yam (Discorea alata), Cassava (Manihot esculenta), Rice (Oryza sativa) and fruits trees such as Mangoes (Mangifera indica), citrus spp. such as oranges, pear, and banana.

The study area has a population of 300,377 with 154,138 males and 146,239 females with a projected annual growth rate of $3.0 \%$ and population density of 286 people per square kilometer (ppsk). It is inhabited by many tribes; the Tivs, Idomas, Etilos, Jukuns, Egede, Hausas, Yorubas and Ibos. The people are largely engage in civil service duties, commercial activities and agrarian peasantry.

\subsection{Methods}

Both primary and secondary data were used. The primary data for this study were mainly coordinates of important points such as wards; a shapefile of the study area was overplayed on them to ascertain their exact positions on the map. The secondary data are satellite images acquired from United State Geological Survey (USGS), in 1994, 2004 and 2014 which were used for land use land cover (LULC) classification. A study period of 20 years (1994_2014) was used for this study due to data availability.

Two basic operations, Image classification, and Urban Detection and Analysis was employed using ArcGIS 10.1 software. The intent of the Image classification is to categorize all pixels in a digital image into one of several land cover classes, or "themes". Supervised classification technique using Maximum Likelihood classification was used to classify the images.

From visual and digital interpretations of the satellite images, different land use and land cover categories were distinguished in the study area. Based on Jensen (2005) land use / land cover classification scheme, the various land use / land cover types within the study area were classified into five; Built-up land, Natural vegetation, Agricultural land, Water body and Bare surfaces. This was done for each of the temporal data (i.e 1994, 2004 and 2014 images that were acquired).

Post classification involves mapping out the various land use types in the study area between the period; 1994, 2004 and 2014 These Land use maps make use of statistical table showing the areal extent (in $\mathrm{km}^{2}$ ) and percentage of different land use type for each study year as well as the trend of change in each class.

A table was developed showing the area in kilometers and the percentage change for each year measured against each land use/land cover type. The comparison of the land use/land cover has assisted in identifying the percentage change; characterizing the land use/land cover change and in calculating the area in kilometers square of the resulting land use/land cover types for each study year and subsequently comparing the results. Thus,

i. To calculate the trend of change, the previous was subtracted from the recent and divided by the previous and multiplies by one hundred (i.e 2014-1994 /1994×100).

ii. To calculate the annual rate of change, percentage changes was divided by one hundred and multiply by the number of years (20 years).

iii. Percentage change was determined by first calculating the change by subtracting the initial value from the later value of the same land use class; i.e. Change in square kilometres=the latter area coverage of landuse/land-cover type of interest minus the initial area coverage of the same land-use/land-cover type.

iv. The percentage of the magnitude of each land use was calculated by dividing the percentage of a particular land use by the total magnitude of the land uses and multiplies by one hundred (i.e 2014-1994/ total magnitude $\times 100$ ).

v. Finally, digital maps showing the spatial distribution of each class and the changes recorded within the study period was produced.

\section{Results and Discussion}

\subsection{Different Land Use Types in the Study Area}

The mapping of different land use types of the study area in 1994, 2004 and 2014 was carried out by classifying the satellite imageries into five major land use types (Table 1).

Table 1. Different Land use Types in makurdi between 1994 and 2014 (in $\mathrm{km}^{2}$ and \%) showing the Trend of change.

\begin{tabular}{|c|c|c|c|c|c|c|}
\hline Land use land cover & 1994 & & 2004 & & 2014 & \\
\hline & Area $\left(\mathrm{km}^{2}\right)$ & $\%$ & Area $\left(\mathbf{k m}^{2}\right)$ & $\%$ & Area $\left(\mathrm{km}^{2}\right)$ & $\%$ \\
\hline Build-up area & 116 & 11 & 252 & 24 & 452 & 43 \\
\hline Natural vegetation & 263 & 25 & 273 & 26 & 95 & 9 \\
\hline Agricultural land & 620 & 59 & 452 & 43 & 420 & 40 \\
\hline Water bodies & 21 & 2 & 53 & 5 & 32 & 3 \\
\hline Bare surface & 32 & 3 & 21 & 2 & 53 & 5 \\
\hline Total & 1,052 & 100 & 1,052 & 100 & 1,052 & 100 \\
\hline
\end{tabular}


Findings as shown in Table 1, and Figure 2 revealed that Built-up area which occupied small portion $\left(116 \mathrm{~km}^{2}\right)$ of the total area in 1994 increased drastically to more than double of the initial size in $2004\left(252 \mathrm{~km}^{2}\right)$, the same level of increment was also noticed between 2004 and $2014\left(452 \mathrm{~km}^{2}\right)$.

Agricultural land which has the highest coverage of the study area in 1994 has decreased significantly throughout the study period (from $59 \%$ to $40 \%$ ). This could majorly be due to the rapid physical development (such as construction of road, buildings etc) and urban expansion which tend to absorb more farmland to accommodate the growing population at the cost of the agricultural land.
Similar decrease trend was recorded by natural vegetation throughout the study period. This finding concurred with the explanations provided by [3, 7], that as built -up areas increases, agricultural land decreases so also natural vegetation. That, it is a chain reaction; as population grows, more surrounding land which is basically agricultural land are absorbed for urban land uses such as constructions of buildings and roads; farmers tend to open up new forest land for agricultural activities (encroachment for agricultural and urban land uses) as well as the accompanying population pressure on forest resources and biodiversity.

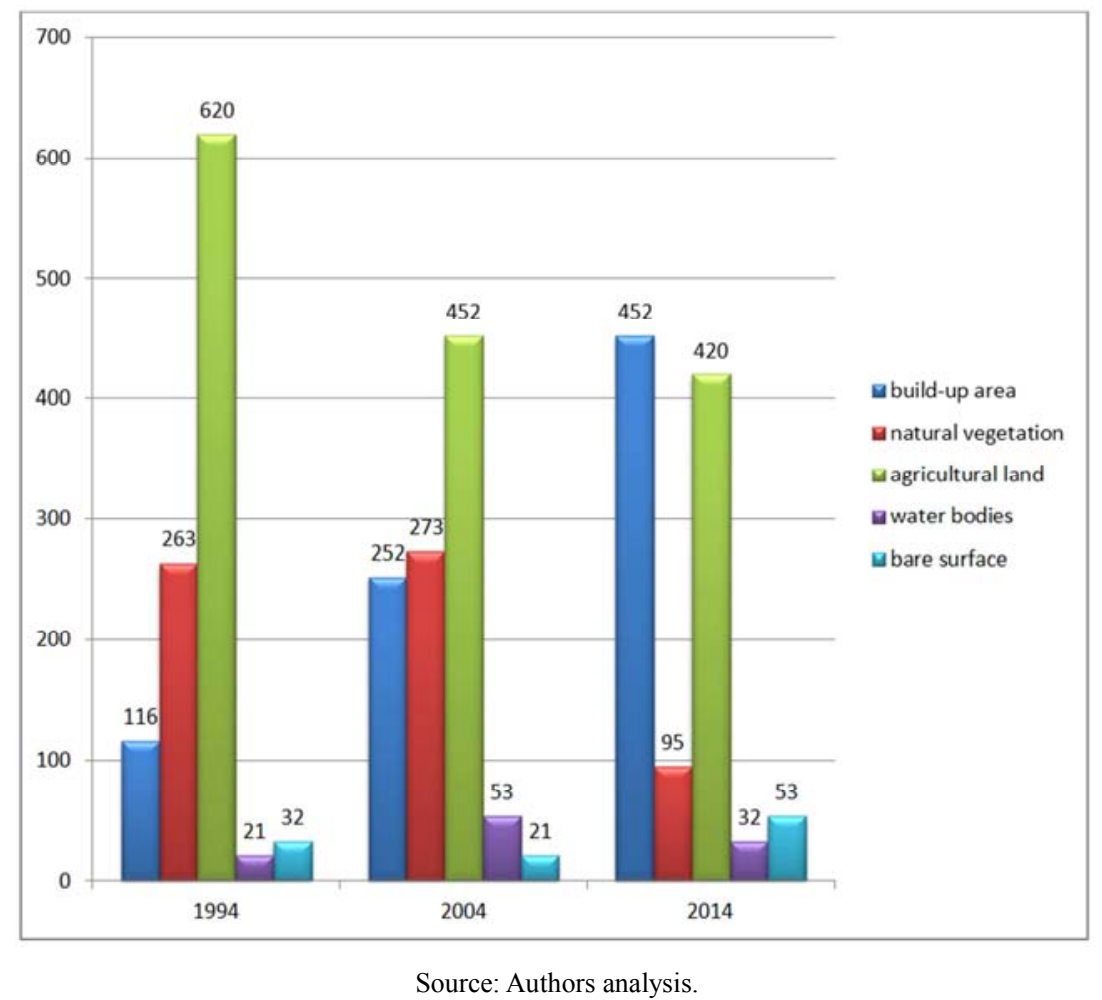

Figure 2. Bar chart showing land use type and area extent (in square $\mathrm{km}$ ) within the period under study.

\subsection{The Magnitude of Change, Percentage Change and Annual Rate of Change in Land Use/Landcover Classes from 1994 to 2014 Is Discussed in Tables 2 and 3 Bellow}

Table 2. The Magnitude of land use change within the period under study (1994-2014).

\begin{tabular}{lllllllll}
\hline $\begin{array}{l}\text { Land use/land } \\
\text { cover }\end{array}$ & $\mathbf{1 9 9 4}$ & $\mathbf{2 0 0 4}$ & $\begin{array}{l}\text { Magnitude of } \\
\text { change }\end{array}$ & $\mathbf{2 0 0 4}$ & $\mathbf{2 0 1 4}$ & $\begin{array}{l}\text { Magnitude } \\
\text { of change }\end{array}$ & $\mathbf{1 9 9 4}$ & $\mathbf{2 0 1 4}$ \\
\hline Build-up area & 116 & 252 & 136 & 252 & 452 & 200 & 116 & 452 \\
change
\end{tabular}

From Table 2 it is observed that the magnitude of change in build-up area between 1994 and 2014 was high. It increased from $116 \mathrm{~km}^{2}(11 \%)$ in 1994 to $252 \mathrm{~km}^{2}(24 \%) 2004$ and $452 \mathrm{~km}^{2}$ (43\%) 2014, resulting in $336 \mathrm{~km}^{2}$ (34\%) as the overall urban growth between 1994 and 2014.

This significant rapid urban growth could be associated with the sitting of Federal and military institution in the study area which consequently lead to rapid physical development such as roads, buildings, industries, and population influx. This findings is in agreement with earlier studies carried out by $[1,4]$, which stated that urban growth is the outcome of the social, economic and political developments which in 
turn lead to urban expansion and growth of large cities.

Table 3. Percentage Change and annual Rate of Change in land use classes between 1994-2014.

\begin{tabular}{|c|c|c|c|c|c|c|}
\hline Land use/land cover & $\begin{array}{l}\text { Percentage change } \\
\text { 1994-2004 }\end{array}$ & $\begin{array}{l}\text { Annual rate } \\
\text { of change }\end{array}$ & $\begin{array}{l}\text { Percentage of } \\
\text { change 2004-2014 }\end{array}$ & $\begin{array}{l}\text { Annual rate of } \\
\text { change }\end{array}$ & $\begin{array}{l}\text { Percentage of } \\
\text { change 1994-2014 }\end{array}$ & $\begin{array}{l}\text { Annual rate } \\
\text { of change }\end{array}$ \\
\hline Build-up area & 117.2 & 11.7 & 79.3 & 7.9 & 289.6 & 14.4 \\
\hline Natural vegetation & 3.8 & 0.4 & -65.2 & -6.5 & -63.8 & -3.1 \\
\hline Agricultural land & -27.0 & -2.7 & -7.0 & -0.7 & -32.2 & -1.6 \\
\hline Water bodies & 152.3 & 15.2 & -39.6 & 3.9 & 52.3 & 2.6 \\
\hline Total & -34.3 & -3.4 & 152.3 & 15.2 & 65.6 & 3.2 \\
\hline
\end{tabular}

As shown in the table above, the annual rate of urbanization was significant throughout the study period. It witnessed change rates of $11.7 \mathrm{~km}^{2}$ between 1994-2004 and $7.9 \mathrm{~km}^{2}$ between 2004-2014. The entire study period (1994 to 2014) recorded a commendable annual urban change rate of $14.4 \mathrm{~km}$ with a consequential negative change rate of agricultural land and natural vegetation.

Agricultural land decreased with an annual change rate of $2.7 \mathrm{~km}^{2}$ between 1994 and 2004; and $-7.0 \mathrm{~km}^{2}$ between 2004 and 2014. Natural vegetation change rate was $-0.4 \mathrm{~km}^{2}$ between $1994-2004$ and $-65.2 \mathrm{~km}^{2}$ between $2004-2014$. The total loss in annual rate between 1994 and 2014 was $1.6 \mathrm{~km}^{2}$ for agricultural land and $-3.1 \mathrm{~km}^{2}$ for natural vegetation. This implies that built-up gained coverage from agricultural land and natural vegetation.

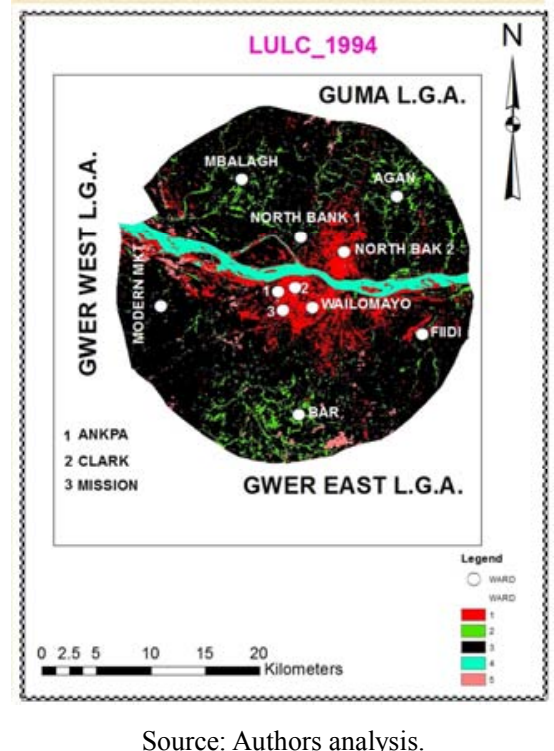

Figure 3. Land use land cover classification of makurdi L. G. A. of 1994.

\subsection{Digital Maps Showing the Spatial Distribution of Arable Land Loss in Study Area from 1994 to 2014}

From the digital map of 1994, it is observed that build up areas were concentrated in wailomayo, Ankpa/wadata, Mission, Clark/Market ward, and part of North Bank one and two Figure 3. In the 2004 digital map urbanization has spread and covered the whole of North Bank one and two, most part Agan, Fiidi, Bar and Modern Market wards Figure 4. However, in the 2014 digital map, most of the arable lands in the study area are taken over by Buildup Figure 5. This increment could be attributed to infrastructural development such as construction of roads and more educational institutions, upgrading of existing social amenities; industrial and commercial developments; and population influx.

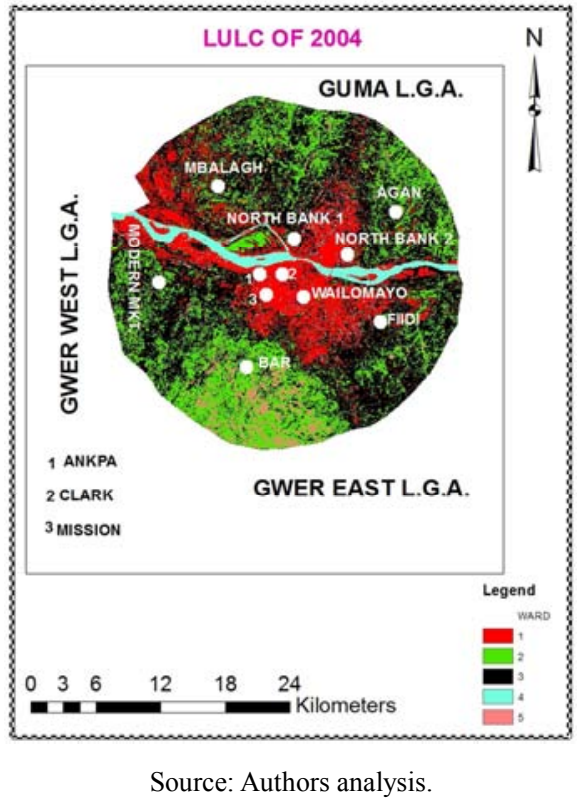

Figure 4. Land use land cover classification of makurdi L. G. A. of 2004.

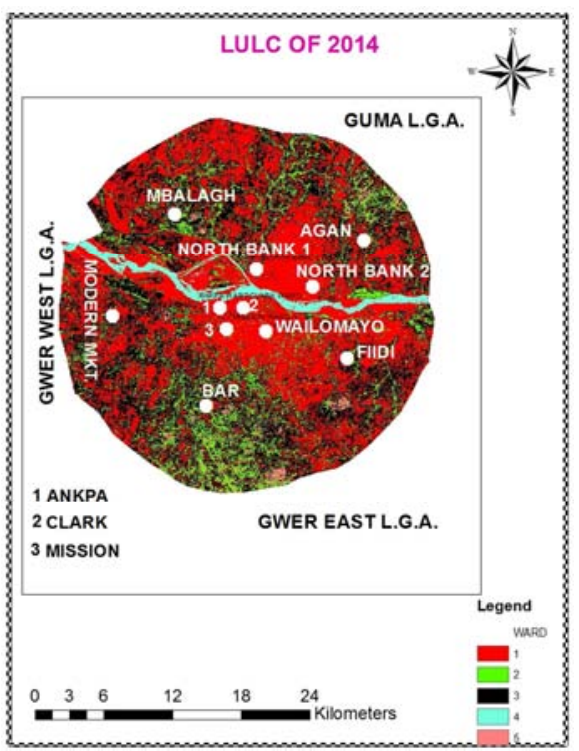

Source: Authors analysis.

Figure 5. Land use land cover classification of makurdi L. G. A. of 2014. 


\section{Conclusion}

This research work displayed the ability of GIS and Remote Sensing in analyzing spatio-temporal dynamics of urbanization. The study area has emerged from being predominantly rural area to a city with an appreciable urbanization level. The result has also shown that the area has lost $200 \mathrm{~km}^{2}$ of agricultural land representing $19 \%$ of the total landmass to urbanization within the study period. Built -up has gained $336 \mathrm{~km}^{2}$ representing $32 \%$ of the total landmass of the study area within the same period. Thus, there is a need to understand the structural dynamics of urbanization in order to formulate sound and effective urban policies. Such policies must be contemporary to turn potential crises into opportunities. Similarly, in the face of rapid reduction of agricultural land to urbanization, agricultural lands be integrated into urban land use planning systems as part of urban development since urban growth and expansion is inevitable.

\section{References}

[1] Francis, Z. N., D. D. Romanus, and K. K. Raphael, Urbanization and its Impact on Agricultural Lands in Growing Cities in Developing Countries: A Case Study of Tamale in Ghana. Modern Social Science Journal, 2013. 2 (2): p. 256287.

[2] Shalaby, A., Assessment of Urban Sprawl Impact on the Agricultural Land in the Nile Delta of Egypt Using Remote Sensing and Digital Soil Map. International Journal of Environmental Sciences 2012. 1 (4): p. 253-262.

[3] Jiang, L., X. Deng, and K. Seto, The Impact of Urban Expansion on Agricultural Land Use intensity in China. Land Use Policy, 2013. 35: p. 33-39.

[4] Oyeleye, O. I., Challenges of Urbanization and Urban Growth in Nigeria. American Journal of Sustainable Cities and Society, 2013. 1 (2).

[5] Ujoh, F., I. D. Kwabe, and O. O. Ifatimehin, Understanding urban sprawl in the Federal Capital City, Abuja: towards sustainable urbanization in Nigeria. Journal of Geography and Regional Planning., 2010. 3 (5): p. 106-113.
[6] Manish, K. T., S. Aruna, and K. Vivek, Mapping and evaluation of urban sprawl using an integrated approach of Remote Sensing and GIS Technique (Review). International Journal of Advanced Technology \& Engineering Research., 2012. 2 (1)

[7] Atu, J. E., et al., The Effects of Urban Sprawl on Peripheral Agricultural Lands in Calabar, Nigeria. International Review of Social Sciences and Humanities 2012. 2 (2): p. 68-76

[8] Lin, L., S. Yohei, and Z. Haihong, Simulating Spatial Urban Expansion based on a Physical Process. Landscape and Urban Planning, 2003. 64 (1-2): p. 67-76.

[9] Milesi, C. D., R. R. Elvidge, and S. W. Nemani, Assessing the impact of urban land development on net primary productivity in the Southeastern United States. Remote Sensing of Environment, 2003. 86: p. 401-410.

[10] Olawole M. O, et al., Monitoring and Assessing Urban Encroachment into Agricultural Land - A Remote Sensing and GIS Based Study of Harare, Zimbabwe. I. Ife Journal of Science 2011. 13 (1).

[11] Angel, S., et al., The dimensions of global urban expansion: Estimates and projections for all countries, 2000-2050.. Progress in Planning 2011. 75 (2): p. 53-107.

[12] Ologunorisa, E. T. and T. Tor, The Changing Rainfall Pattern and Its Implication for Flood Frequency in Makurdi, Northern Nigeria. J. Appl. Sci. Environ. Manage., 2006. 10 (3): p. 97 102.

[13] Keiser, J., U., et al., Urbanization in Sub-Saharan Africa and Implication for Malaria Control. The American Society of Tropical Medicine and Hygiene., 2004: p. 118-127.

[14] Cohen, B., Urbanization in developing countries: Current trends, future projections, and key challenges for sustainability. Technology in Society 2005. 28: p. 63-80.

[15] Abah, R. C., Causes of seasonal flooding in flood plains: a case of Makurdi, Northern Nigeria. Intl. J. Envtal Studies 2012. 69 (6): p. 904-912.

[16] Ayoade, J. O., Introduction to climatology for the tropics. Ibadan: Spectrum Books. pp. 179-184. 1983. 